\title{
The Effect of Bacteria on Early Age Strength of CEM I and CEM II Cementitious Composites
}

\author{
Tsz Ying Hui ${ }^{1}$, Lorena Skevi ${ }^{1, *}$, Bianca Reeksting ${ }^{2}$, Susanne Gebhard ${ }^{2}$ and Kevin Paine ${ }^{1}$ (D) \\ 1 BRE Centre for Innovative Construction Materials, Department of Architecture and Civil Engineering, \\ University of Bath, Bath BA2 7AY, UK; huitszyingvicky@gmail.com (T.Y.H.); k.paine@bath.ac.uk (K.P.) \\ 2 Milner Centre for Evolution, Department of Biology and Biochemistry, University of Bath, Bath BA2 7AY, UK; \\ b.j.reeksting@bath.ac.uk (B.R.); s.gebhard@bath.ac.uk (S.G.) \\ * Correspondence: 1.skevi@bath.ac.uk; Tel.: +44-739-531-0212
}

Citation: Hui, T.Y.; Skevi, L.; Reeksting, B.; Gebhard, S.; Paine, K The Effect of Bacteria on Early Age Strength of CEM I and CEM II Cementitious Composites.

Sustainability 2022, 14, 773. https:// doi.org/10.3390/su14020773

Academic Editor: Syed Minhaj Saleem Kazmi

Received: 16 November 2021

Accepted: 7 January 2022

Published: 11 January 2022

Publisher's Note: MDPI stays neutral with regard to jurisdictional claims in published maps and institutional affiliations.

Copyright: (c) 2022 by the authors. Licensee MDPI, Basel, Switzerland. This article is an open access article distributed under the terms and conditions of the Creative Commons Attribution (CC BY) license (https:/ / creativecommons.org/licenses/by/ $4.0 /)$.

\begin{abstract}
Despite being associated with lower carbon emissions, CEM II cementitious materials exhibit reduced early age strength compared to that of CEM I. Several studies have demonstrated early age strength improvements by incorporating bacterial cells in concrete. In this study, live vegetative bacteria and dead bacteria killed in two different ways were used to explore whether changes in strength are related to the bacteria's viability or their surface morphology. Compressive and flexural strength tests were performed at mortars with and without bacteria for both CEM I and CEM II cement. Their microstructure, porosity and mineralogy were also examined. No net strength gain was recorded for either CEM I or CEM II bacterial mortars compared to non-bacterial controls, although changes in the porosity were reported. It is proposed that two phenomena, one causing strength-reduction and one causing strength-gain, took place in the bacterial specimens, simultaneously. It is suggested that each phenomenon is dependent on the alkalinity of the cement matrix, which differs between CEM I and CEM II mortars at early age. Nevertheless, in neither case could it be recommended that the addition of bacteria is an effective way of increasing the early age strength of mortars.
\end{abstract}

Keywords: bacterial mortar; low $\mathrm{CO}_{2}$ cement; compressive strength; pore volume

\section{Introduction}

The production of cement is responsible for approximately $35 \%$ of $\mathrm{CO}_{2}$ released globally by the construction activities [1] the majority of which is due to the burning of fuels and decarbonisation of limestone necessary to form Portland Cement (PC), termed CEM I in European standards [2]. To reduce the embodied carbon of concrete structures, a growing interest in the use of cement with lower embodied carbon has occurred. For example, CEM II cements permit up to $35 \%$ of the composite cement to be a secondary main constituent, usually limestone, fly ash or ground granulated blast furnace slag, that has embodied carbon levels up to two magnitudes lower than PC. This means that the embodied carbon of CEM II can be 25-30\% lower than CEM I [3]. In many environments, CEM II cement is often preferable to the higher carbon CEM I cements [4]. However, concretes made with CEM II do have lower early age strength (EAS) than CEM I concretes [5]. On this basis, concrete made with CEM II can need longer construction time, leading to increased overall cost in practice. It has been suggested that the low EAS could be overcome by the addition of bacteria to the concrete during mixing [6,7].

The use of bacteria in concrete has been increasingly researched since the beginning of the 21st century. The popularity grew in the construction material sector due to their potential in delivering autonomous self-healing properties through microbiologically induced calcite precipitation (MICP). The mechanism is triggered when a crack develops in concrete, allowing moisture in the air to stimulate dormant spores for germination. The spores then transform into vegetative cells in the presence of organic compounds that 
enable them to grow and thus promote the precipitation of calcite through their metabolic activities [8]. Eventually, the mineral deposition fills in the concrete crack without the need for any human interference. The MICP mechanism has been demonstrated in many studies of self-healing concrete [9-11], which has spurred further research on bacterial concrete.

Alternatively, the inclusion of live vegetative (i.e., non-spore) bacterial cells in mortars has also been commonly explored in similar studies. In these, parameters such as bacterial species, bacterial concentration, cement type, presence and composition of nutrients were investigated. A review of previous findings has been tabulated in Table 1 . In the study by Ghosh et al. $[12,13$ ] it was shown that bacterial samples had significantly lower void volumes than control samples, which was attributed to the spatial expansion of bacterial cells within the structure. The authors further proposed that the viability of bacteria was maintained due to their access to nutrients at curing, enabling dense MICP to be carried out. However, the findings regarding the strength performance of bacterial mortars were not entirely positive. For instance, Ghosh et al. found no effect on EAS by immobilisation of live Escherichia coli into mortars [13]. In fact, some studies found that a correlation between MICP and compressive strength was unlikely. Jonkers et al. [14] indicated that the number of live Bacillus cohnii (B. cohnii) cells in their concrete samples decreased by $90 \%$ after 42 days. Moreover, Bundur et al. [15] demonstrated that only $0.1 \%$ of the bacterial cells in the cement matrix remained viable after seven days of water suspension. This was generally attributed to the lack of oxygen and nutrients, as well as the high alkalinity and curing stress within cementitious materials.

To investigate the relationship between bacterial metabolic activity and mortar strength, research with dead bacteria has also been carried out. Ramachandran, Ramakrishnan and Bang [16] found strength enhancement in both live and dead bacterial mortars, proposing that the bacteria acted as natural fibres within the concrete, densifying the mortar structure and enhancing its mechanical properties. The findings also demonstrated that the mechanical strength of samples with dead bacteria decreased after seven days. It was suggested that the organic material of the dead cells decomposed with time, creating voids in the mortar matrix thus weakening the mortar structure. Pei et al. [17] also reported decreased strength in mortars containing dead cells, but enhanced strength in mortars amended with bacteria cell walls. The negatively charged cell walls were considered to act as nucleation sites for the formation of calcite and calcium silicate hydrate (C-S-H), thus leading to strength improvement. In dead bacteria, however, other negatively charged bacterial constituents of the cell (proteins, polysaccharides, etc.) were assumed to counteract the nucleation effect of the cells walls resulting in a strength decline. The nucleation site hypothesis as a strength improvement mechanism was also supported by Chaurasia et al. [18] using negatively charged live cells, and by Skevi et al. [19] using both live and dead cells. Skevi et al. also argued that chemical interactions between the cell components and the dissolved ions of the cementitious solution potentially led to the formation of more hydrates and consequently to the increased strength.

Although the surface properties of the cells and their interaction with their surrounding environment within concrete were suggested to greatly influence the mechanical performance of concrete, little to no research has been reported considering variations in the surface of the cells as well as in the cementitious environment. In this investigation, live vegetative cells and dead cells were added to mortars to assess the impact on the strength. The bacteria were killed in two different ways, by autoclave and UV-light, to investigate whether changes in performance could be related to the morphology of the cell surface. Mortar composition was also considered by using two types of cement, CEM I and CEM II. Hence, a better understanding in the feasibility of new bacterial cement composites with higher strength and lower carbon footprints can be achieved, driving the cement industry to a more sustainable future. 
Table 1. Results of various bacterial strains and their respective concentrations and compressive strengths.

\begin{tabular}{|c|c|c|c|c|c|}
\hline $\begin{array}{c}\text { Bacterial } \\
\text { Status }\end{array}$ & Bacterial Strain & Bacterial Concentration & $\begin{array}{l}\text { Cement } \\
\text { Type }\end{array}$ & $\begin{array}{c}\text { Max/Min \% Change } \\
\text { in Strength }\end{array}$ & Reference \\
\hline \multirow{8}{*}{ Live } & Shewanella & $10^{5}$ cells $/ \mathrm{mL}$ water & OPC 53 & $+25 \%$ at 28 days & [12] \\
\hline & Shewanella & $10^{5}$ cells $/ \mathrm{mL}$ water & OPC 53 & $+19 \%$ at 28 days & {$[13]$} \\
\hline & Sporosarcina pasteurii & $7.6 \times 10^{3}$ cells $/ \mathrm{mL}$ concrete & CEM I & $+19 \%$ at 28 days & [16] \\
\hline & Arthrobacter crystallopoietes & 0.8 at $\mathrm{OD}_{600}$ & PC & $-11.7 \%$ at 7 days & [20] \\
\hline & Sporosarcinapasteurii & 0.8 at $\mathrm{OD}_{600}$ & PC & $-17.3 \%$ at 28 days & [20] \\
\hline & $\begin{array}{c}\text { ACRN3 (ureolytic } \\
\text { environmental isolate) }\end{array}$ & $10^{6}$ cells $/ \mathrm{mL}$ water & CPO 40 & $-8.16 \%$ at 28 days & {$[21]$} \\
\hline & $\begin{array}{c}\text { ACRN5 (ureolytic } \\
\text { environmental isolate) }\end{array}$ & $10^{5}$ cells $/ \mathrm{mL}$ water & СРO 40 & $-8.7 \%$ at 28 days & [21] \\
\hline & Bacillus cohnii & $10^{5}$ cells $/ \mathrm{mL}$ water & CEM II & $-12 \%$ at 3 days & [19] \\
\hline \multirow[t]{2}{*}{ Dead } & $\begin{array}{l}\text { Sporosarcina pasteurii and } \\
\text { Pseudomonas aeruginosa }\end{array}$ & $\begin{array}{c}3.8 \times 10^{7} \text { cells } / \mathrm{mL} \text { concrete } \\
\text { each }\end{array}$ & CEM I & $+11 \%$ at 28 days & [16] \\
\hline & Bacillus cohnii & $10^{7}$ cells $/ \mathrm{mL}$ water & CEM II & $+35 \%$ at 3 days & [19] \\
\hline
\end{tabular}

\section{Materials and Methods}

\subsection{Bacteria and Growth Conditions}

For this study, B. cohnii DSM 6037 from the German Collection of Microorganisms and Cell Cultures (DSMZ) were used. B. cohnii is an alkaliphilic species capable of producing calcium carbonate through the oxidation of organic materials. The bacteria were routinely cultured in lysogeny broth (LB), adjusted to $\mathrm{pH} 9.7$ with $100 \mathrm{~mL} / \mathrm{L}$ of Na-sesquicarbonate solution $\left(42 \mathrm{~g} / \mathrm{L} \mathrm{NaHCO}_{3}\right.$ and $\left.53 \mathrm{~g} / \mathrm{L} \mathrm{Na}_{2} \mathrm{CO}_{3}\right)$. The cultures were grown at $30{ }^{\circ} \mathrm{C}$ and agitated at $150 \mathrm{rpm}$ on a shaker. The bacterial growth was monitored by optical density at a wavelength of $600 \mathrm{~nm}\left(\mathrm{OD}_{600}\right)$ and final cell concentrations were $1.5 \times 10^{9}$ cells $/ \mathrm{mL}$ $\left(\mathrm{OD}_{600} 1=8.8 \times 10^{8}\right)$. Cells were split equally between the three treatments: live cells, autoclaved, and UV-light killed. Autoclaved cells were killed in an autoclave at $121{ }^{\circ} \mathrm{C}$ under 2 bar pressure for 15 min and UV-killed cells by exposure to UV light on a transilluminator table for $2.5 \mathrm{~h}$. Viable cell counts were performed via dilution and spread-plating.

\subsection{Cement Mortar and Paste Sample Preparation}

Portland Cement (CEM I 52.5R) and Portland limestone cement (CEM II/ A-L 32.5R) were used in this experiment, both of which conform with the BS EN 197-1:2011 standard [22]. The mineralogy of CEMI and CEMII cement powders was determined with $X$-ray Diffraction analysis (XRD) presented in Figures 1 and 2 respectively. Alite is prominent in both cement types, but as expected, CEM II had a more intense peak of calcite than CEM I due to the replacement of clinker with 6-20\% of limestone in these types of cement. The presence of a small percentage of limestone in CEM I cements $(<5 \%)$ is common in UK produced cements, which explains the presence of calcite in CEM I as well.

With each of the CEM I and CEM II cement, four types of mortar samples and cement paste samples were prepared: control (no bacteria), live bacteria, autoclaved bacteria and ultraviolet-killed bacteria as shown in Table 2. The cells were diluted in tap water to obtain the concentration of $10^{7}$ cells / $\mathrm{mL}$ for all types of cells used, then added as of part the water content for mortar or paste specimens. Mortar samples of $160 \times 40 \times 40 \mathrm{~mm}^{3}$ were prepared according to the BS EN 196-1 at a water-to-cement ratio of 0.5. A total of 72 mortar samples were demoulded after setting for $24 \mathrm{~h}$ at room temperature, and then were water-cured at $20^{\circ} \mathrm{C}$ until their testing time at 3, 7 and 28 days. Similarly, the same types of cement pastes were prepared for isothermal analysis with calorimetry and more analytic techniques. Each paste sample consisted of $30 \mathrm{~g}$ cement and $15 \mathrm{~mL}$ tap water. Bacterial pastes contained cells of the three types (live, autoclaved, UV-killed) at 
$10^{7}$ cells $/ \mathrm{mL}$ concentration diluted in the mixing water. The samples were mixed in the calorimetry cups resulting in cylindrical specimens of $52 \mathrm{~mm}$ diameter and $11 \mathrm{~mm}$ height.

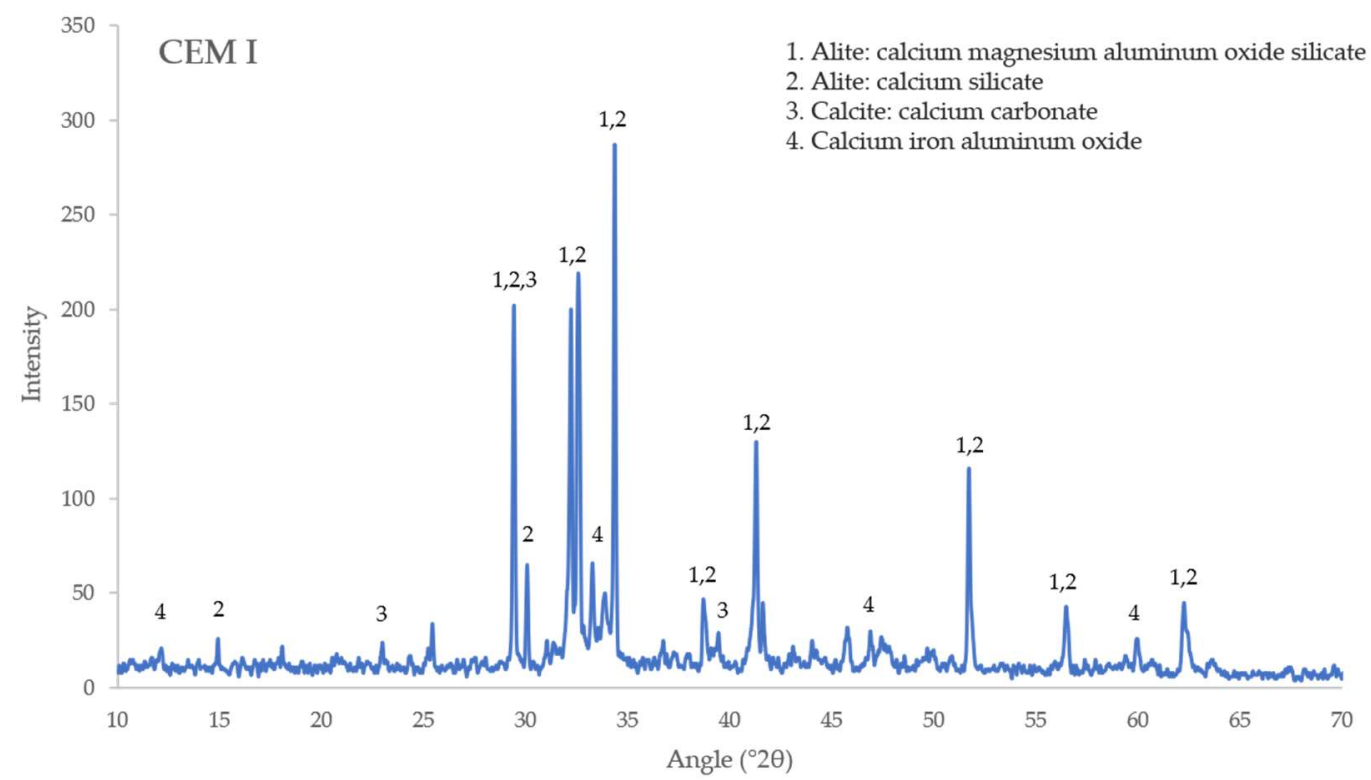

Figure 1. XRD spectra giving the mineralogy of the CEMI 52.5R powder cement used in this study, where: calcium magnesium aluminum oxide silicate: $\mathrm{Ca}_{54} \mathrm{MgAl}_{2} \mathrm{Si}_{16} \mathrm{O}_{90}$, calcium silicate: $\mathrm{Ca}_{3} \mathrm{SiO}_{5}$, calcium carbonate: $\mathrm{CaCO}_{3}$, calcium iron aluminum oxide: $\mathrm{Ca}_{2} \mathrm{Fe}_{1.52} \mathrm{Al}_{48} \mathrm{O}_{5}$.

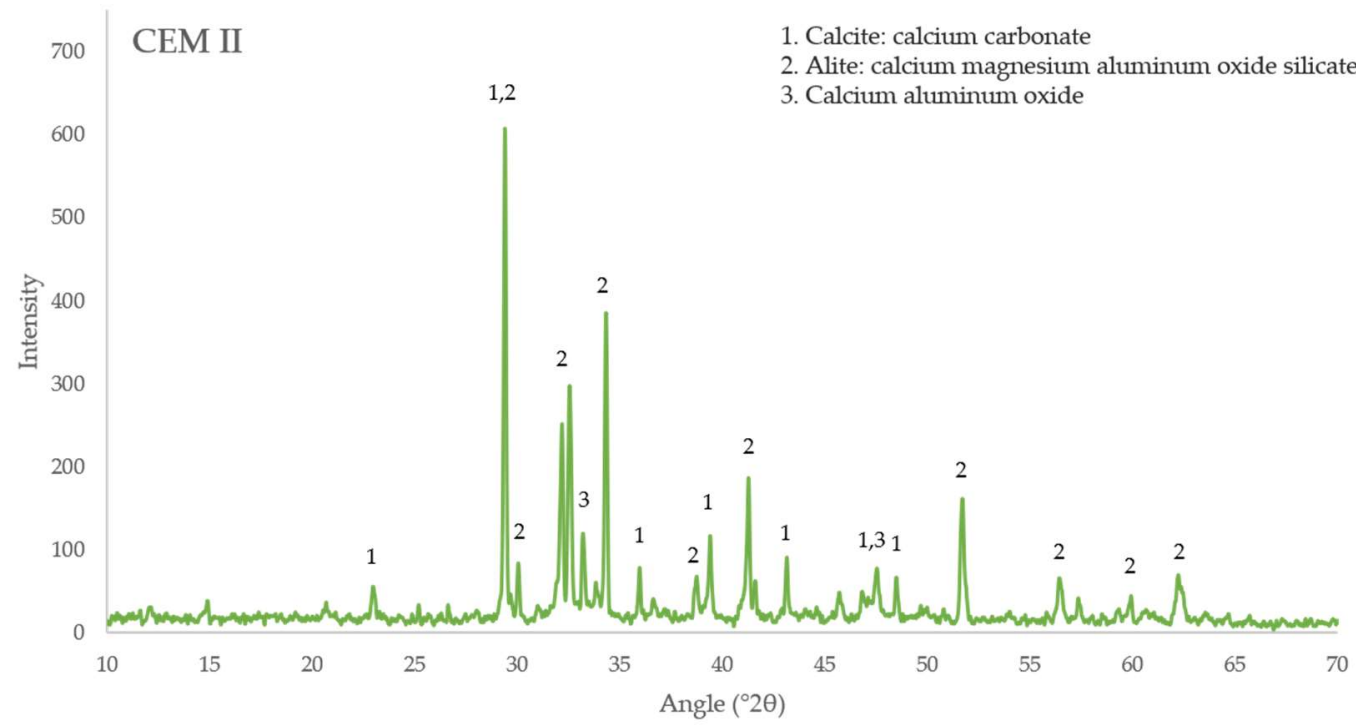

Figure 2. XRD spectra giving the mineralogy of CEMII/A-L 32.5R powder cement used in this study, where: calcium carbonate: $\mathrm{CaCO}_{3}$, calcium magnesium aluminum oxide silicate: $\mathrm{Ca}_{54} \mathrm{MgAl}_{2} \mathrm{Si}_{16} \mathrm{O}_{90}$, calcium aluminum oxide: $\mathrm{Ca}_{3} \mathrm{Al}_{2} \mathrm{O}_{5}$. 
Table 2. Materials, mix designs and notations of cement mortar samples.

\begin{tabular}{cccccc}
\hline Sample & $\begin{array}{c}\text { Cement (g) } \\
\text { CEM I 52.5R or } \\
\text { CEM II/A-L 32.5R }\end{array}$ & $\begin{array}{c}\text { Water (mL) } \\
\text { Tap Water }\end{array}$ & $\begin{array}{c}\text { Sand (g) } \\
\text { Standard Sand }\end{array}$ & $\begin{array}{c}\text { Bacteria Concentration } \\
\text { (cells/mL) } \\
\text { Bacillus cohnii }\end{array}$ & Bacteria Status \\
\hline C1 & $450($ CEM I) & 225 & 1350 & 0 & - \\
LBC1 & $450($ CEM I) & 225 & 1350 & $10^{7}$ & Live \\
ABC1 & $450($ CEM I) & 225 & 1350 & $10^{7}$ & Autoclave-killed \\
UBC1 & $450($ CEM I) & 225 & 1350 & $10^{7}$ & UV-killed \\
C2 & $450($ CEM II) & 225 & 1350 & $10^{7}$ & - \\
LBC2 & $450($ CEM II) & 225 & 1350 & $10^{7}$ & Live \\
ABC2 & $450($ CEM II) & 225 & 1350 & $10^{7}$ & Autoclave-killed \\
UBC2 & $450($ CEM II) & 225 & & UV-killed \\
\hline
\end{tabular}

\subsection{Experimental Methods}

\subsubsection{Flexural and Compressive Strength}

In accordance with BS EN 196-1, the flexural strengths of mortar specimens were tested in a three-point bending after 3, 7 and 28 days of water curing. For each set of mix designs, three mortar specimens were tested to obtain the mean flexural strength. After the flexural tests, the compressive strengths of mortars were assessed on each half of the specimen. For each set of mix design, six halves of mortar specimens were assessed. Mean values were calculated as the final data. It should be noted that 28-day flexural and compressive strength tests were not conducted on CEM II mortars due to COVID-19 lockdown regulations in 2020. However, since this study focuses on the impact of bacteria on the EAS of the mortars, only the 3 and 7 days data were taken into consideration when drawing conclusions.

\subsubsection{Calorimetry}

Heat evolution of the exothermic hydration process between water and cement was studied using isothermal conduction calorimetry (I-Cal 4000). After mixing of each paste, samples were immediately placed in the unit at $20^{\circ} \mathrm{C}$ for $72 \mathrm{~h}$, and the heat production during the exothermic hydration process calculated.

\subsubsection{Microscopic Analysis}

For the microscopic analyses, samples were obtained after the completion of previous tests. These were the 3-day-old cement pastes from calorimetry and the 3-day-old mortars from compressive tests. These samples were crushed into pieces whose diameters ranged between 4 and $8 \mathrm{~mm}$. The hydration in the samples was stopped at 3 days. This was achieved using the solvent exchange method described by Calabria-Holley et al. [23], by immersing the specimens' pieces in isopropanol $\left(\mathrm{C}_{3} \mathrm{H}_{7} \mathrm{OH}\right)$ of $99 \%$ purity for $24 \mathrm{~h}$. After that, they were placed in a desiccator for another $24 \mathrm{~h}$ to vacuum-dry, and then stored in plastic bags inside the desiccator until the testing day. The microstructure of the cement pastes and mortars was assessed using Scanning Electron Microscopy (SEM) with a JEOL JSM-6480LV microscope at $10 \mathrm{kV}$ accelerating voltage. Energy-Dispersive X-ray Spectroscopy (EDX) tests were also carried out with the same apparatus,. SEM and EDX tests were not performed on 3-day CEM I paste samples and 3-day CEM II mortars due to COVID-19 lockdown regulations in 2020.

\subsubsection{Porosity Analysis}

For mercury intrusion porosimetry (MIP), desiccated 3-day cement paste samples were obtained after the microscopic analysis and were then crushed into 4 to $8 \mathrm{~mm}$ sized pieces. The porosity analysis was performed using Thermofisher Pascal 140 for low pressure from $<0.1 \mathrm{kPa}$ to $400 \mathrm{kPa}$ and Pascal 440 for high pressures from atmospheric pressure to $400 \mathrm{MPa}$. Low pressure tests were performed on the samples with compressed air before the high-pressure tests using dielectric oil. 


\subsubsection{X-ray Diffraction Analysis}

Powder X-ray Diffraction analysis (XRD) was performed on 3-day-old powdered cement paste samples. The analysis was conducted on STOE STADI P double setup with Mythen detectors using $\mathrm{Cu}-\mathrm{Ka}_{1}$ radiation. Data collection was carried out in a $2 \theta$ range of $5^{\circ}$ to $78^{\circ}$ with a $0.015^{\circ}$ step size, using a rate of $600 \mathrm{~s} /$ step.

\section{Results}

\subsection{Flexural and Compressive Strength}

Figure 3 demonstrates the flexural strength data of all samples at 3, 7 and 28 days, as well as the percentage variation (Change\%) of the bacterial samples compared to the control. Similarly, data obtained from compressive strength tests at 3,7 and 28 days are presented in Figure 4. In general, bacterial CEM I and CEM II samples did not achieve a higher flexural or compressive strength performance than the control. For CEM I mortars, bacterial samples demonstrated a decrease in both flexural and compressive strength compared to control samples. Specifically, a decreasing trend was observed, with the highest being $\mathrm{C} 1$, through $\mathrm{LBC} 1$ and $\mathrm{ABC} 1$, to $\mathrm{UBC} 1$ at the lowest. At day 3, the UBC1 samples had a compressive strength $31 \%$ lower than the control. In CEM II samples, all four mixes had similar levels of EAS performance, with the maximum difference from the control being a $12 \%$ and $9 \%$ decrease in flexural and compressive results, respectively, for the UBC2 mortars. Therefore, it is suggested that the effect of the bacteria on the EAS of CEM II samples was not as negative as it was for samples made with CEM I.

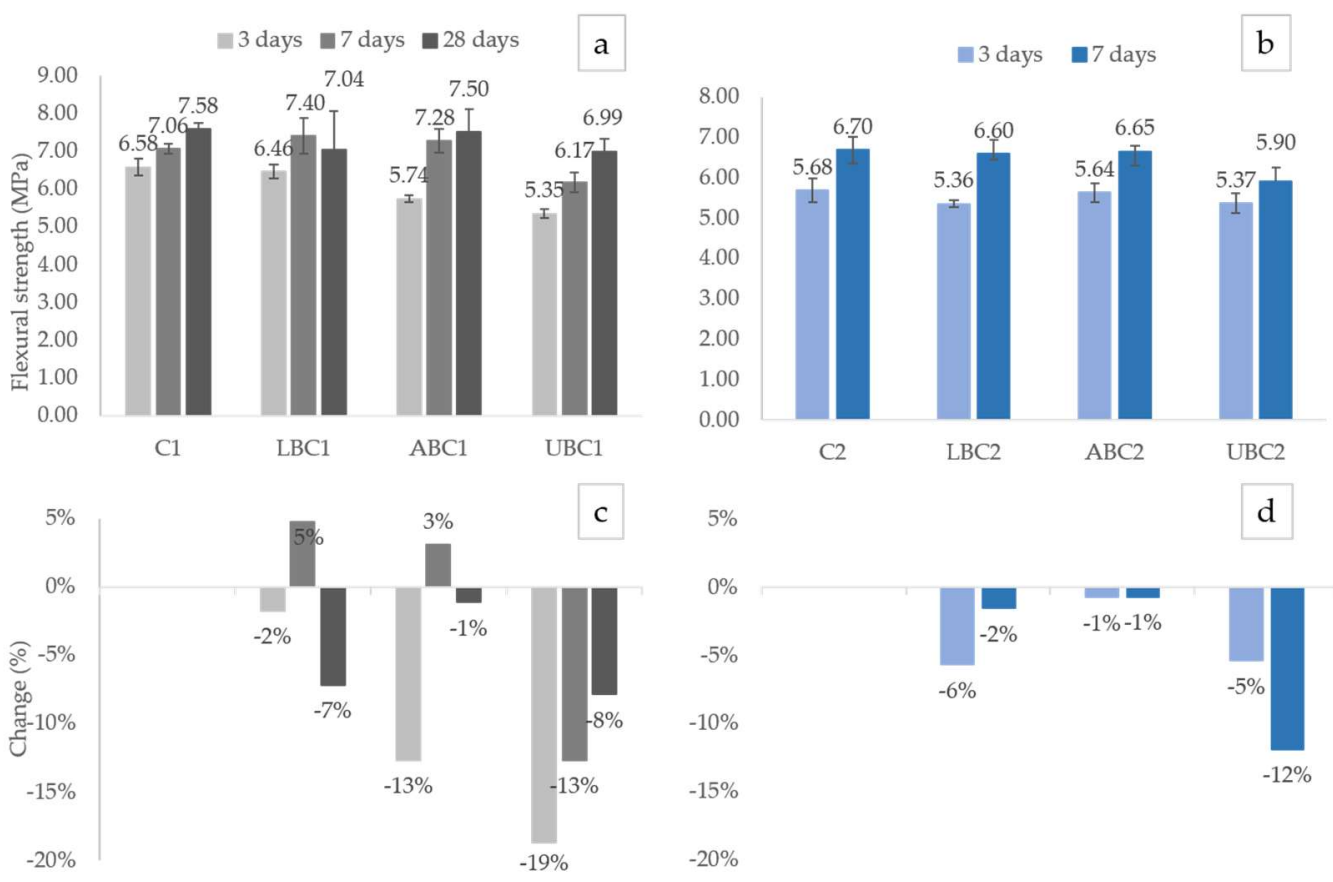

Figure 3. Flexural strength of control and bacterial samples using both CEM I (a) and CEM II (b) cement and percentage strength change of the bacterial samples for CEM I (c) and CEM II (d) at 3, 7 and 28 days. Note: missing day 28 results from CEM II samples. [C: control, LBC: live bacteria cells, ABC: autoclaved bacteria cells, and UBC: UV-killed bacteria cells]. 

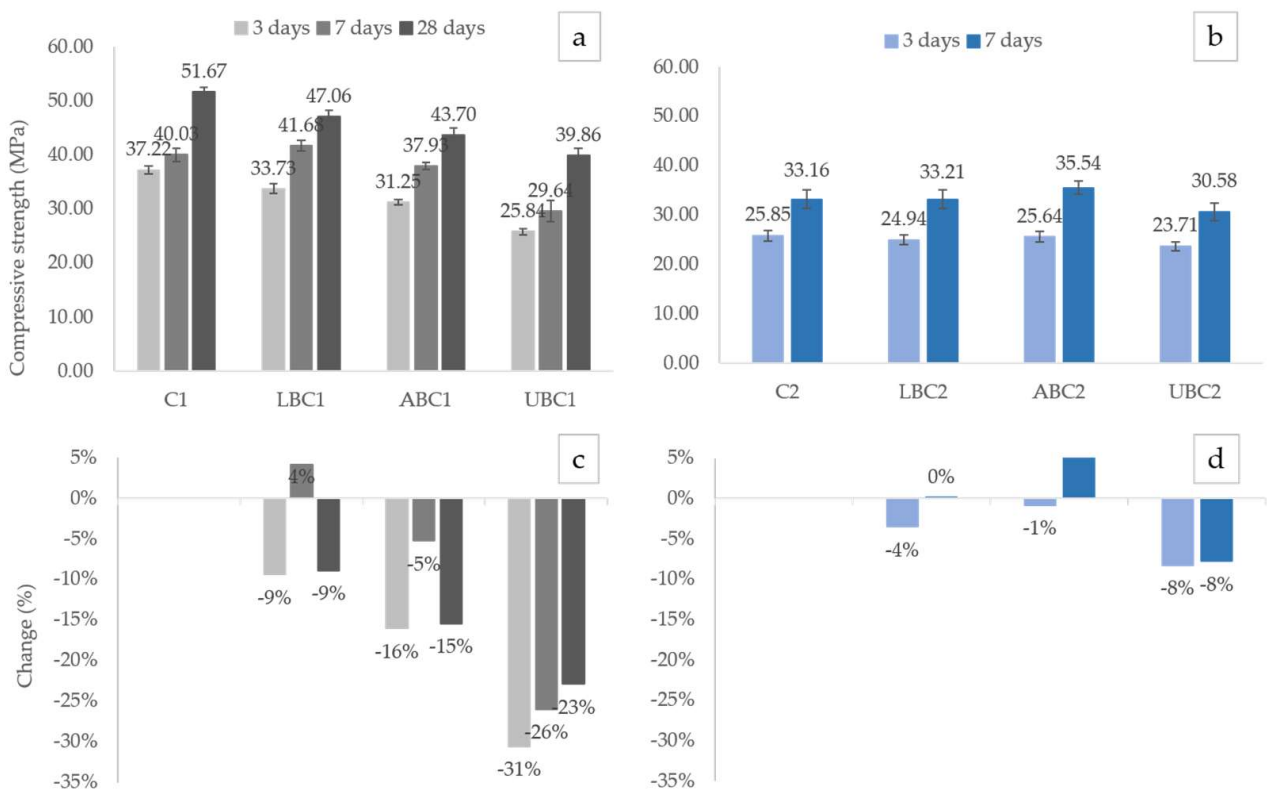

Figure 4. Compressive strength of control and bacterial samples using both CEM I (a) and CEM II (b) cement and percentage strength change of the bacterial samples for CEM I (c) and CEM II (d) at 3, 7 and 28 days. Note: missing day 28 results from CEM II samples. [C: control, LBC: live bacteria cells, ABC: autoclaved bacteria cells, and UBC: UV-killed bacteria cells].

\subsection{Hydration Rate}

Figures 5 and 6, respectively, present the heat production rate (Figures 5a and 6a) and the accumulated heat release (Figures $5 \mathrm{~b}$ and $6 \mathrm{~b}$ ) of the CEM I and CEM II paste samples during hydration as tested with isothermal calorimetry. Across CEM I samples, no significant changes were observed between bacterial and control pastes, in which the peaks of hydration were all observed at $12 \mathrm{~h}$. Concurrent peaks of hydration were also found at $12 \mathrm{~h}$ for CEM II samples, as well as some heat variation from 12 to $30 \mathrm{~h}$. It is shown that the UBC2 sample containing UV-killed bacteria had the highest peak of around $1.9 \mathrm{~W} / \mathrm{kg}$, while that of ABC2 with autoclaved cells had the lowest at approximately $1.7 \mathrm{~W} / \mathrm{kg}$, and this difference was retained for $30 \mathrm{~h}$. Beyond that time, ABC2 and LBC2 pastes behaved similarly to the control, while the heat rate was slightly lower for the UBC2 sample.

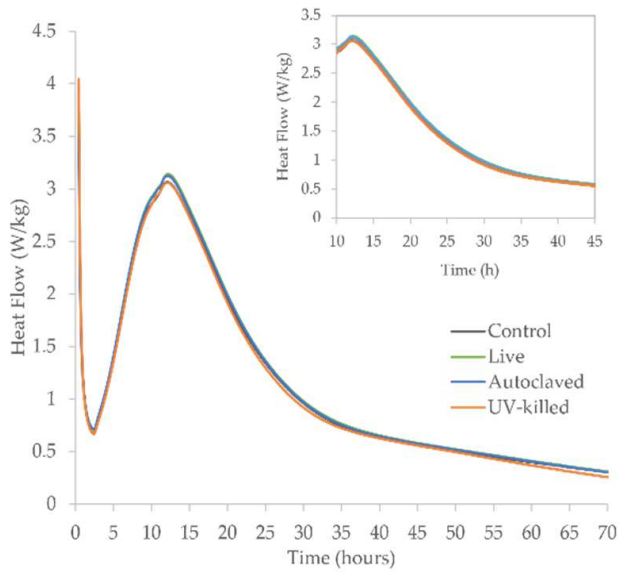

a

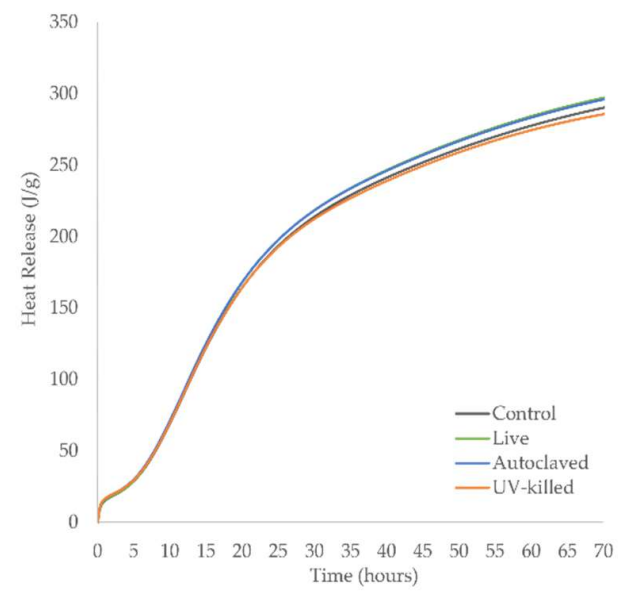

b

Figure 5. Heat production rate (a) and accumulated heat release (b) during hydration in control and bacterial samples made with CEM I. [C1: control, LBC1: live bacteria cells, ABC1: autoclaved bacteria cells, and UBC1: UV-killed bacteria cells]. 


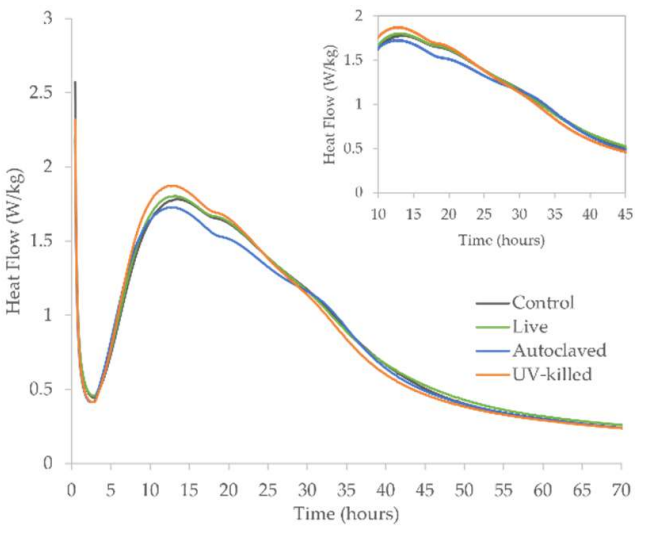

a

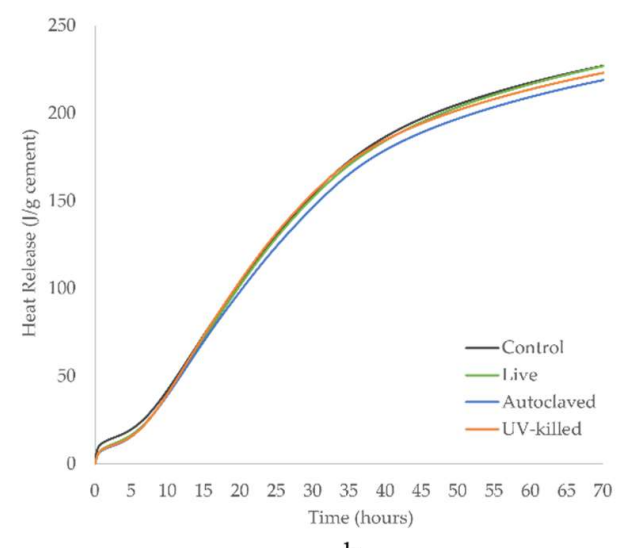

b

Figure 6. Heat production rate (a) and accumulated heat release (b) during hydration in control and bacterial samples made with CEM II. [C2: control, LBC2: live bacteria cells, ABC2: autoclaved bacteria cells, and UBC2: UV-killed bacteria cells].

\subsection{Microscopic Analysis}

SEM images obtained from CEM I mortars at three days are shown in Figure 7. Despite the decreased strength of the bacterial samples, especially the UBC1, microscopic images showed no significant differences across CEM I control and bacterial samples, in which foil-shaped calcium silicate hydrates (C-S-H) and needle-like ettringite phases are both found as indicated in yellow arrows.
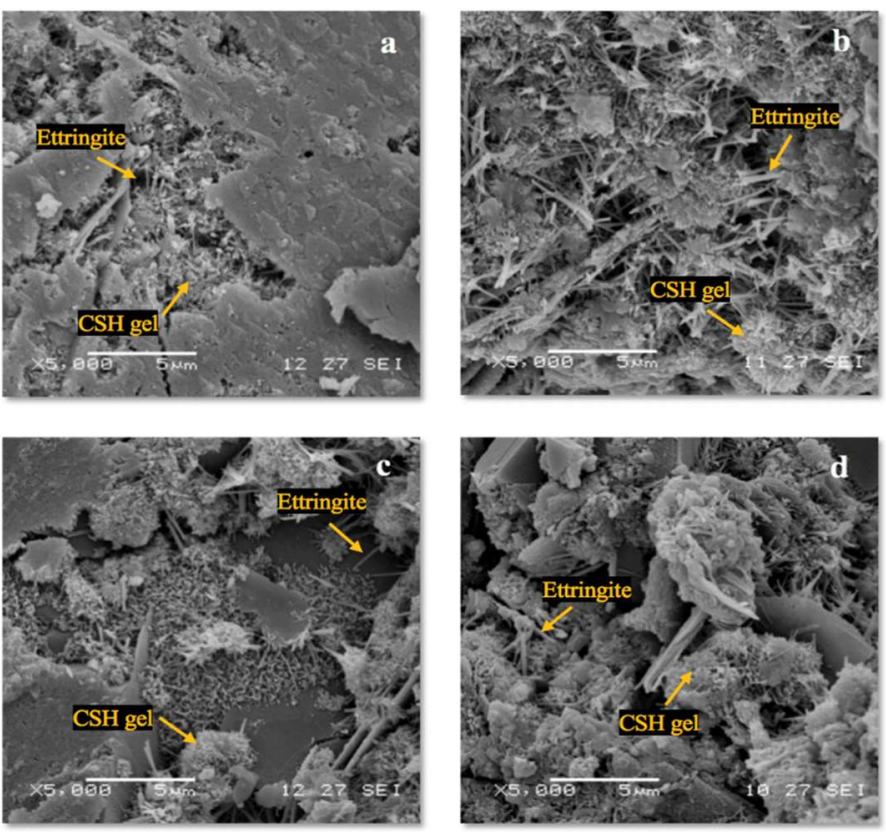

Figure 7. SEM images of control sample (a), live (b), autoclaved (c) and UV-killed (d) bacterial mortars using CEM I cement at three days ( $\times 5000$ magnification).

In the case of CEM II samples, in which bacterial mortars demonstrated similar strength to the control, SEM images of CEM II pastes (not shown here) did not reveal any major difference in the microstructure. An EDX analysis was then carried out to examine whether a strengthening mechanism took place in these samples, partly compensating for the negative effect of the bacterial addition. The elemental analysis of three-days-old CEM II pastes is given in Figure $8 \mathrm{a}$, while Figure $8 \mathrm{~b}$ shows the region $(550 \times 800 \mu \mathrm{m})$ approximately used for EDX analysis for the control sample, which was carried out similarly for the rest of the samples. Figure 8a suggests that there was no considerable elemental difference 
between CEM II control and bacterial pastes, corresponding to the SEM images. Based on the above data, in which no major discrepancy between control and bacterial samples is noticed, it is tentatively suggested that the availability of 3-day CEM II mortars and CEM I pastes microscopy data would have not affected the conclusions reached.

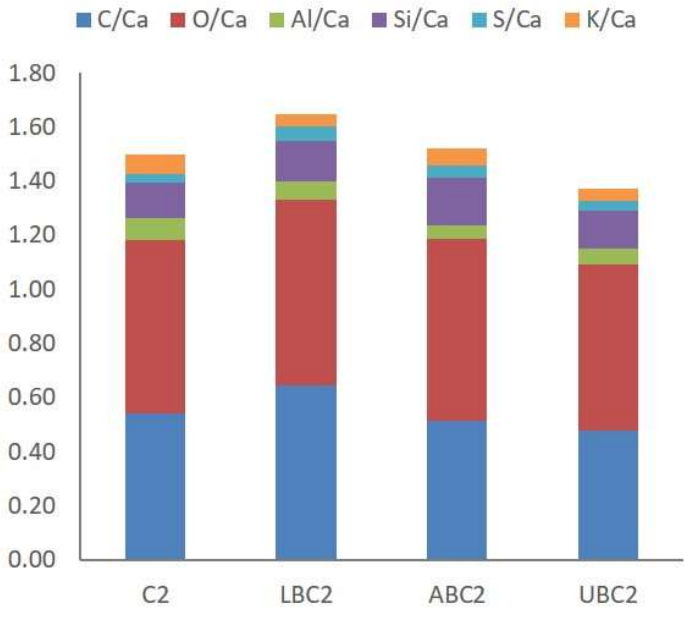

a

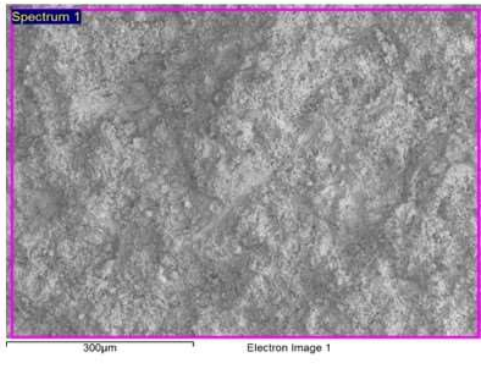

b

Figure 8. (a) Elemental analysis (EDX) of CEM II three-day-old paste samples for: control (C2), live (LBC2), autoclaved (ABC2) and UV-killed (UBC2). Results are given in weight $\%$ ratios of the elements $(\mathrm{C}, \mathrm{O}, \mathrm{Al}, \mathrm{Si}, \mathrm{S}, \mathrm{K})$ in relation to calcium (Ca). (b) The examined area for the control sample, similar areas were examined for all samples.

\subsection{Porosity Analysis}

For the MIP analysis, cumulative and derivative curves of CEM I and CEM II samples are shown in Figures 9 and 10, respectively. As indicated below, the total percolated pore volumes across CEM I samples were collectively around $300 \mathrm{~mm}^{3} / \mathrm{g}$. Contrarily, the critical pore entry diameters were less comparable to each other, showing that the maximum pore diameter was larger in LBC1 pastes with live cells than the control and the samples containing the dead bacteria, $\mathrm{ABC} 1$ and $\mathrm{UBC} 1$.

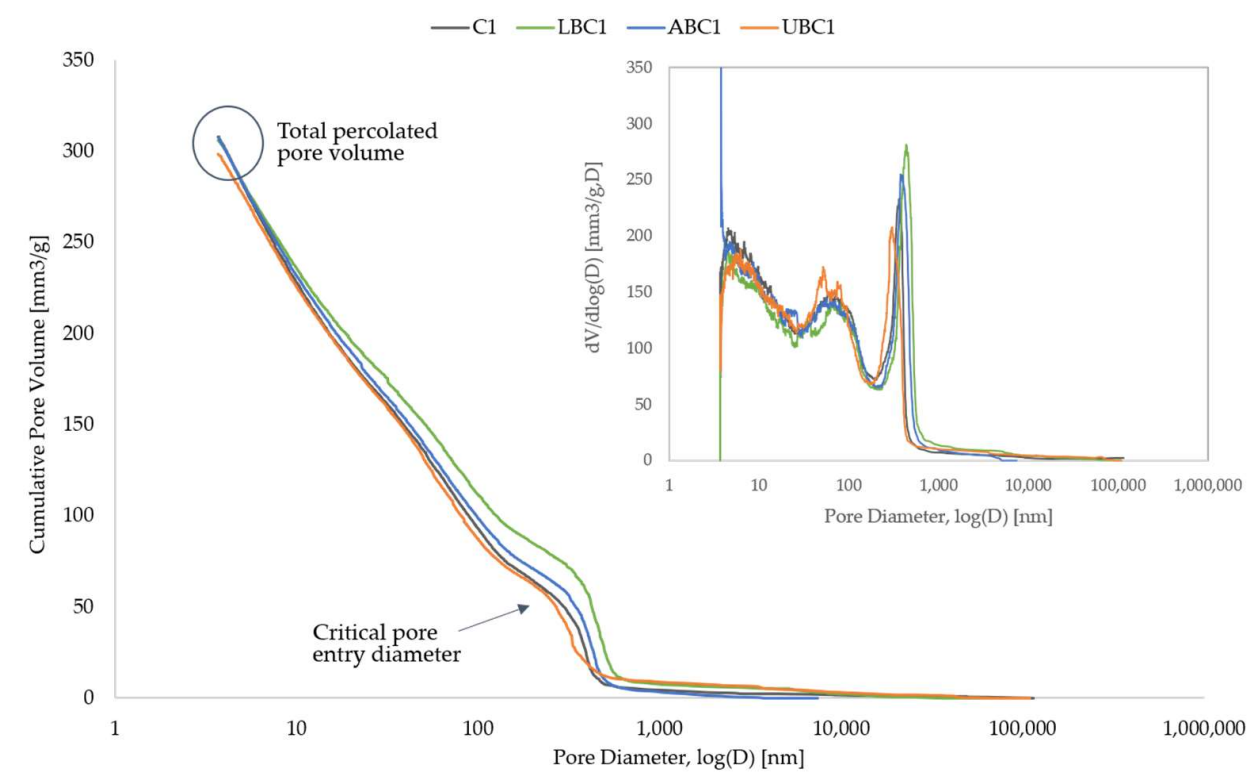

Figure 9. MIP cumulative (bottom) and derivative curves (top right) of control (C1), live (LBC1), autoclaved (ABC1) and UV-killed (UBC1) bacterial samples using CEM I cement at three days. 


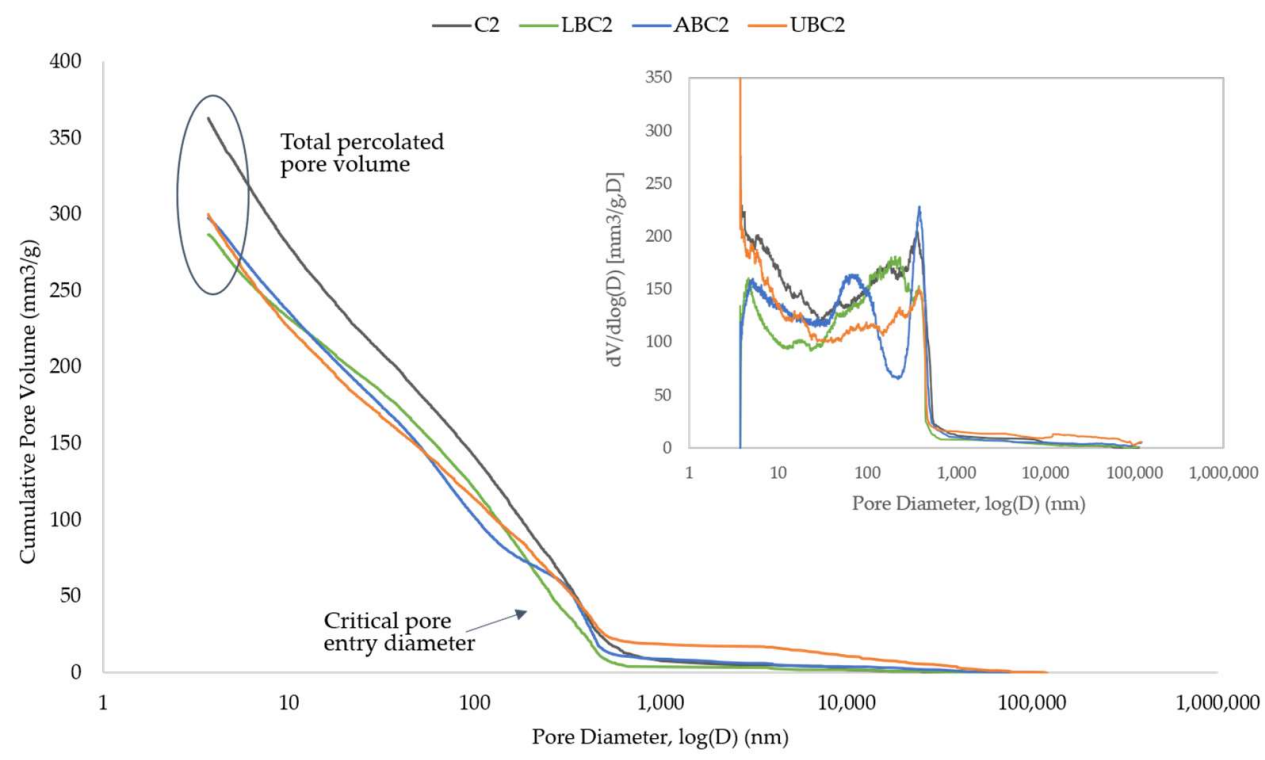

Figure 10. MIP cumulative (bottom) and derivative curves (top right) of control (C2), live (LBC2), autoclaved (ABC2) and UV-killed (UBC2) bacterial samples using CEM II cement at three days.

On the other hand, in CEM II specimens, the total percolated pore volume of all bacterial samples was significantly lower, by more than $60 \mathrm{~mm}^{3} / \mathrm{g}$, than that of the control sample. Logarithmic differential distribution $(\mathrm{dV} / \mathrm{d} \log (\mathrm{D})$, shown in the upper right corner of Figure 10, shows a varying distribution of pore sizes across the samples, especially between those containing dead cells (ABC2 and UBC2) and the control. This was not noticed in CEM I samples that presented similar pore distribution.

\subsection{X-ray Diffraction Analysis}

PXRD plots of CEM I and CEM II cement paste samples are presented in Figures 11 and 12, respectively. In general, there were no considerable changes between the control and bacterial samples both for the CEM I and CEM II pastes, as shown from the occurrence of peaks at the same angle. As expected, more calcite (CC) was present in CEM II specimens. Calcium silicate phases $\left(\mathrm{C}_{2} \mathrm{~S}, \mathrm{C}_{3} \mathrm{~S}\right)$ were also found in all mix designs as well as hydration products like ettringite $(\mathrm{Aft})$ and portlandite $(\mathrm{CH})$.

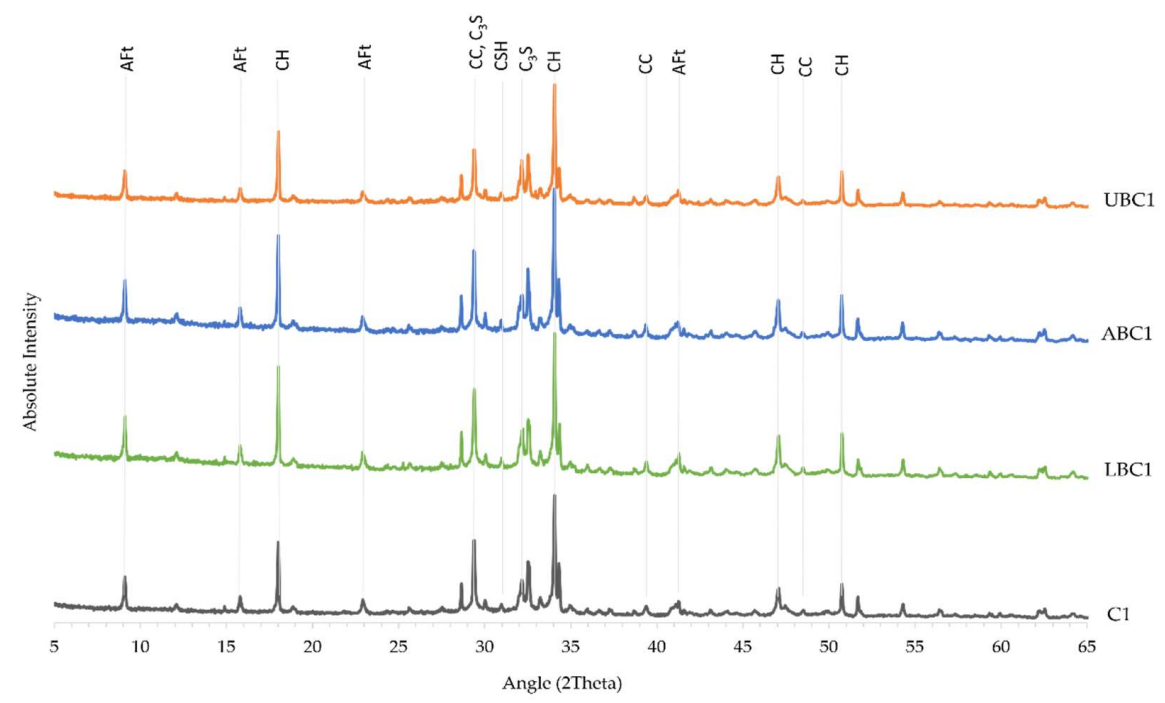

Figure 11. PXRD plot of control (C1), live (LBC1), autoclaved (ABC1) and UV-killed (UBC1) bacterial samples using CEM I cement at three days. AFt: ettringite, $\mathrm{CH}$ : portlandite, $\mathrm{CC}$ : calcite, $\mathrm{C}_{3} \mathrm{~S}$ : alite, $\mathrm{C}_{2} \mathrm{~S}$ : belite. 


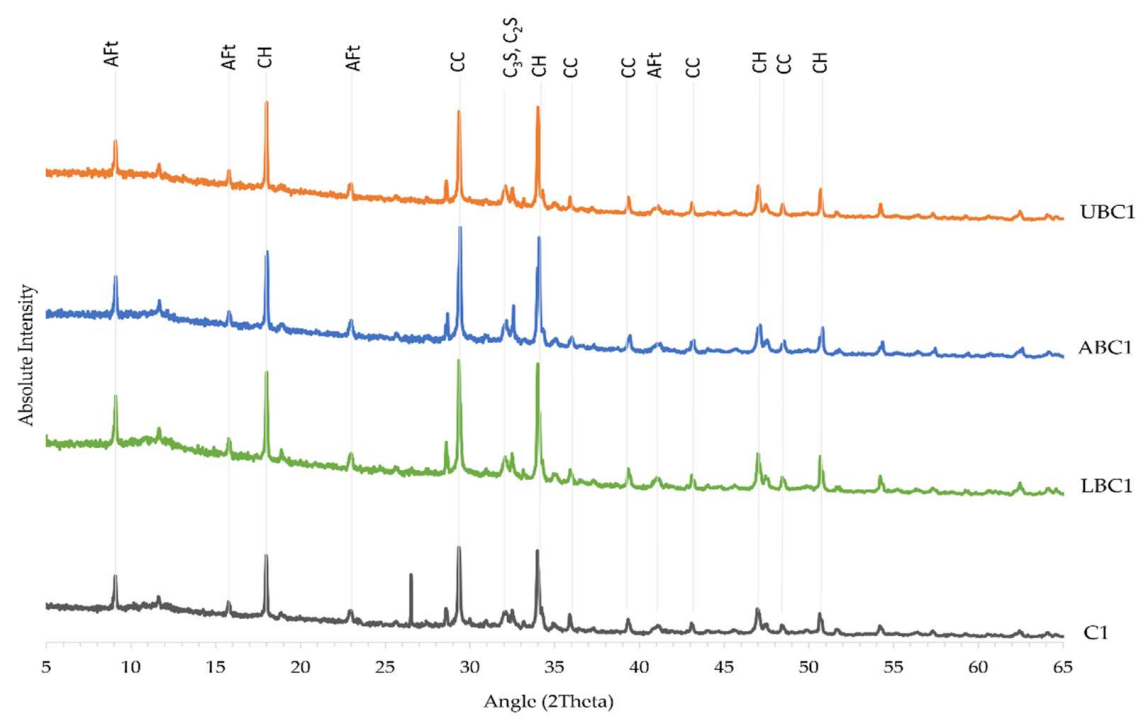

Figure 12. PXRD plot of control (C2), live (LBC2), autoclaved (ABC2) and UV-killed (UBC2) bacterial samples using CEM II cement at three days. AFt: ettringite, $\mathrm{CH}$ : portlandite, CC: calcite, C3S: alite, C2S: belite.

\section{Discussion}

\subsection{Effect of Bacteria on the Strength of CEM I Specimens}

\subsubsection{Presence of Bacteria}

As presented from the flexural and compressive strength results, it was evident that the addition of live or dead B. cohnii cells produced no EAS enhancement on the cement mortars in this study, which contradicts some similar studies [18,19] but is in line with others [14,17]. A hypothesis for the strength decrease could be the 'side effect' of bacteria behaving as organic inclusions, causing inevitable cell decompositions. Consequently, voids could have been introduced to the cement matrix, decreasing the mortar's strength [16]. However, no significant differences between the percolated pore volume of control and bacterial CEM I samples were found in the MIP results of this study. Nonetheless, percolated pore volume only represents the connected pores within the cement matrix, which is not equivalent to the total pore volume. In a different approach, decomposition of the bacteria could result in the release of bacterial components such as proteins and peptidoglycans in the mortar, which, reacting with cementitious components, may have had a negative effect on the strength development of the samples. In addition, earlier research stated that the optimal bacterial concentration for mortar strength enhancement was $10^{5}$ cells $/ \mathrm{mL}[12,16]$, whereas the cell concentration used in this study was $10^{7}$ cells $/ \mathrm{mL}$. It is possible that a high presence of cells increased the chance of bacterial death due to oxygen depletion. This would result in more bacterial constituents available to interact within the cementitious matrix to the detriment of the strength. The analytic techniques used in this study, i.e., calorimetry, PXRD and SEM analysis, offered little to understanding the processes of such an interaction between the bacteria and the cementitious components, as the difference of the hydration rate, microstructure and mineral composition across the samples, control and bacterial, were trivial.

\subsubsection{Bacterial Status}

A decreasing trend was observed in the strength results of bacterial samples, which suggested that bacterial status influenced the mortar strength. In particular, the bacterial status regarding the most to the least weakening effect is listed as follows: (1) UV-killed, (2) autoclaved and (3) live bacteria. It is possible to explain this finding using the aboveproposed hypothesis. Considering that the decomposition rate of organic matter depends on the quality of dead material available [24], differences in the released cell components could be responsible for the weakening pattern across bacterial samples. The weakest 
performance from UV-killed sample could be explained by the broad damage of the cells during UV inactivation. Liu et al. [25] indicated that UV light was capable of breaking down the outermost layer of $E$. coli cells, in addition to UV-induced damage of cell-internal proteins and DNA [26]. Damage to the cell envelope of the bacteria would lead to leakage of cellular contents due to osmotic pressure, and interaction of these components with the cementitious solution could explain the most negative influence of this bacterial addition on mortar strength.

On the other hand, in $\mathrm{ABC} 1$ mortars bacteria were treated in steam in an autoclave for inactivation. An experiment performed by Hossain et al. [27] indicated that autoclaving Enterococcus faecalis, E. coli and Bacillus sphaericus did not impair their cell structures. Hence, the autoclaved bacteria could have retained their cell integrity, which would explain the lower decomposition rate and, therefore, the lower strength loss compared to the UBC1 samples. Mortars containing live cells had the least negative effect out of all bacterial specimens, which could be related to the cell's higher structural integrity when first added to the samples. Slow inactivation of the bacteria during the mixing and curing process would likely have delayed the availability of dead material, hence minimising the weakening effect.

\subsection{Effect of Bacteria on the Strength of CEM II Specimens}

4.2.1. Presence of Bacteria

The lack of significant EAS differences observed between CEM II control and bacterial samples suggests that the bacteria had less effect on the EAS in these mortars. However, results from calorimetry and MIP demonstrated that chemical and physical differences were present between control and bacterial CEM II specimens, which were not observed in CEMI samples. More intriguingly, the proposed decomposition of bacteria seemingly did not affect the CEM II samples in the same way as those of CEM I. Cement composites made with CEM I are highly alkaline with common values in mortars being between $\mathrm{pH}$ 12-13 [28]. The partial replacement of clinker with limestone in CEMII A-L results in lower $\mathrm{pH}$ in this cement type [28]. Considering that the $\mathrm{pH}$ scale is logarithmic, a difference by one value in this scale between the two materials would mean that CEM I is 10 times more alkaline than CEM II. This could imply that less or slower cell decomposition took place in the less alkaline CEM II environment, reducing the negative impact of the released bacterial components on these mortars.

Furthermore, the lower porosity found in the CEM II bacterial specimens compared to the control suggests that a strength-enhancing phenomenon may have occurred in CEM II samples leading to more compact mortars. This could compensate for the EAS decrease caused by bacterial decomposition, resulting in little to no effect on overall EAS. Since some bacteria likely have retained their cell structures or even viability in CEM II mortars, they may have acted as nucleation sites enabling the formation of additional hydration products. Similarly, calcite minerals could have also used cells as nucleation points, with the ion exchange of aqueous $\mathrm{CO}_{3}{ }^{2-}$ and $\mathrm{OH}^{-}$producing a seeding effect on C-S-H formation, thus densifying the cement matrix $[12,19,29]$. It should also be noted that no evidence of MICP occurred in this study, which was expected since no nutrients were provided for the bacteria.

\subsubsection{Bacterial Status}

As discussed above, the lower $\mathrm{pH}$ in CEM II samples likely favoured the live and autoclaved cells to retain their structure. This would allow some intact cells to act as nucleation sites and thus to have little to no adverse effect on the EAS of the mortars, unlike in CEM I samples where live and autoclaved cells would have rapidly deteriorated. Bacteria killed by UV-light had the most negative impact on the EAS of the CEM II mortars; however this was significantly less severe than in CEM I samples. It seems, therefore, that the already structurally impaired UV-killed bacteria benefited the most from the less alkaline environment of CEM II samples. 


\section{Conclusions}

It is proposed that two separate phenomena, one of which is strength-reducing and one of which is strength-enhancing, take place when bacteria are added to cementitious samples during the mixing phase. The individual effect of the two phenomena was found to be dependent on the alkalinity of the cement matrix, as demonstrated across the results of CEM I and CEM II samples. In CEM I, it is proposed that the high alkalinity promoted cell degradation in bacterial samples and the consequent release of cell components in the cement matrix, which compromised its strength. This resulted in higher strength loss when the most damaged cells of UV-light killed bacteria were used and less loss when cells with lower decomposition rates, live or autoclaved, were used. In contrast, as CEM II paste is less alkaline, this phenomenon had less effect, potentially leaving some cells viable and/or structurally intact. Consequently, the survival and existence of these cells was proposed to induce a strength-gaining phenomenon in CEM II bacterial samples via physical and chemical interactions between the cells and cement compounds, which led to lower porosity and eventually compensated for the EAS loss caused by the cell degradation. To conclude, the use of bacteria per se does not guarantee EAS enhancement in CEM I or CEM II cementitious composites but will affect the physical properties of the paste. CEM II was shown to provide a more favourable environment for the bacteria.

Author Contributions: Conceptualization, T.Y.H. and K.P.; methodology, T.Y.H., L.S., K.P. and S.G.; formal analysis, T.Y.H. and L.S.; investigation, T.Y.H. and B.R.; resources, K.P. and S.G.; data curation, T.Y.H. and L.S.; writing — original draft preparation, T.Y.H.; writing—review and editing, L.S., B.R., S.G. and K.P.; visualization, T.Y.H. and L.S.; supervision, L.S. and K.P.; project administration, K.P.; funding acquisition, K.P. and S.G. All authors have read and agreed to the published version of the manuscript.

Funding: This research was funded by UKRI/EPSRC (Project No. EP/ PO2081X/1) as part of the Resilient Materials for Life (RM4L) project. The doctoral scholarship of L.S. was funded by BRE Trust.

Data Availability Statement: All data relevant to this study are reported in the results section of this publication.

Acknowledgments: The authors gratefully acknowledge the technical staff within the Department of Architecture and Civil Engineering, the Department of Biology and Biochemistry and the Material and the Chemical Characterisation Facility $\left(\mathrm{MC}^{2}\right)$ at the University of Bath for technical support and assistance in this work.

Conflicts of Interest: The authors declare no conflict of interest. The funders had no role in the design of the study; in the collection, analyses, or interpretation of data; in the writing of the manuscript; or in the decision to publish the results.

\section{References}

1. Habert, G.; Miller, S.A.; John, V.M.; Provis, J.L.; Favier, A.; Horvath, A.; Scrivener, K.L. Environmental impacts and decarbonization strategies in the cement and concrete industries. Nat. Rev. Earth Environ. 2020, 1, 559-573. [CrossRef]

2. Benhelal, E.; Zahedi, G.; Shamsaei, E.; Bahadori, A. Global strategies and potentials to curb $\mathrm{CO}_{2}$ emissions in cement industry. J. Clean. Prod. 2013, 51, 142-161. [CrossRef]

3. Leese, R.; Casey, D. MPA Cement Mineral Products Association Fact Sheet 18: Embodied CO2e of UK Cement, Additions and Cementitious Material. Fact Sheet 18. Available online: https://cement.mineralproducts.org/documents/Factsheet_18.pdf (accessed on 10 October 2021).

4. Dhir, R.K.; Mccarthy, M.J.; Zhou, S.; Tittle, P.A.J. Role of cement content in specifications for concrete durability: Cement type influences. Proc. Inst. Civ. Eng. Struct. Build. 2004, 157, 113-127. [CrossRef]

5. Concrete Society. Technical Report 74: Cementitious Materials: The Effect of Ggbs, Fly Ash, Silica Fume and Limestone Fines on the Properties of Concrete; Concrete Society: Camberley, UK, 2011.

6. Su, Y.; Feng, J.; Jin, P.; Qian, C. Influence of bacterial self-healing agent on early age performance of cement-based materials. Constr. Build. Mater. 2019, 218, 224-234. [CrossRef]

7. Chidara, R.; Nagulagama, R.; Yadav, S. Achievement of Early Compressive Strength in Concrete Using Sporosarcina pasteurii Bacteria as an Admixture. Adv. Civ. Eng. 2014, 2014, 435948.

8. Hoffmann, T.D.; Reeksting, B.J.; Gebhard, S. Bacteria-induced mineral precipitation: A mechanistic review. Microbiology 2021, 167, 001049. [CrossRef] 
9. De Belie, N.; Wang, J.; Bundur, Z.B.; Paine, K. Bacteria-based concrete. In Eco-Efficient Repair and Rehabilitation of Concrete Infrastructures; Pacheco-Torgal, F., Melchers, R.E., Shi, X., De Belie, N., Tittelboom, K., Sáez, A., Eds.; Woodhead Publishing: Cambridge, UK, 2018; pp. 531-567.

10. Justo-Reinoso, I.; Heath, A.; Gebhard, S.; Paine, K. Aerobic non-ureolytic bacteria-based self-healing cementitious composites: A comprehensive review. J. Build. Eng. 2021, 42, 102834. [CrossRef]

11. Kim, H.; Son, H.M.; Seo, J.; Lee, H.K. Recent advances in microbial viability and self-healing performance in bacterial-based cementitious materials: A review. Constr. Build. Mater. 2021, 274, 122094. [CrossRef]

12. Ghosh, P.; Mandal, S.; Pal, S.; Bandyopadhyaya, G.; Chattopadhyay, B.D. Development of bioconcrete material using an enrichment culture of novel thermophilic anaerobic bacteria. Indian J. Exp. Biol. 2006, 44, 336-339.

13. Ghosh, P.; Mandal, S.; Chattopadhyay, B.D.; Pal, S. Use of microorganism to improve the strength of cement mortar. Cem. Concr. Res. 2005, 35, 1980-1983. [CrossRef]

14. Jonkers, H.M.; Thijssen, A.; Muyzer, G.; Copuroglu, O.; Schlangen, E. Application of bacteria as self-healing agent for the development of sustainable concrete. Ecol. Eng. 2010, 36, 230-235. [CrossRef]

15. Bundur, Z.B.; Amiri, A.; Ersan, Y.C.; Boon, N.; De Belie, N. Impact of air entraining admixtures on biogenic calcium carbonate precipitation and bacterial viability. Cem. Concr. Res. 2017, 98, 44-49. [CrossRef]

16. Ramachandran, S.K.; Ramakrishnan, V.; Bang, S.S. Remediation of concrete using micro-organisms. ACI Mater. J. 2001, 98, 3-9.

17. Pei, R.; Liu, J.; Wang, S.; Yang, M. Use of bacterial cell walls to improve the mechanical performance of concrete. Cem. Concr. Compos. 2013, 39, 122-130. [CrossRef]

18. Chaurasia, L.; Bisht, V.; Singh, L.P.; Gupta, S. A novel approach of biomineralization for improving micro and macro-properties of concrete. Constr. Build. Mater. 2019, 195, 340-351. [CrossRef]

19. Skevi, L.; Reeksting, B.J.; Hoffmann, T.D.; Gebhard, S.; Paine, K. Incorporation of bacteria in concrete: The case against MICP as a means for strength improvement. Cem. Concr. Compos. 2021, 120, 104056. [CrossRef]

20. Park, S.J.; Park, Y.-M.; Chun, W.Y.; Kim, W.J.; Ghim, S.Y. Calcite-forming bacteria for compressive strength improvement in mortar. J. Microbiol. Biotechnol. 2010, 20, 782-788.

21. Alonso, M.J.C.; Ortiz, C.E.L.; Perez, S.O.G.; Narayanasamy, R.; Fajardo San Miguel, G.d.J.; Hernández, H.H.; Balagurusamy, N. Improved strength and durability of concrete through metabolic activity of ureolytic bacteria. Environ. Sci. Pollut. Res. 2018, 25, 21451-21458. [CrossRef]

22. BS EN 197-1:2011; Cement-Composition, Specifications and Conformity Criteria for Common Cements. British Standards Institution (BSI): London, UK, 2011.

23. Calabria-Holley, J.; Paine, K.; Papatzani, S. Effects of nanosilica on the calcium silicate hydrates in Portland cement-fly ash systems. Adv. Cem. Res. 2015, 27, 187-200. [CrossRef]

24. Chapin, F.S.; Matson, P.A.; Vitousek, P.M. Principles of Terrestrial Ecosystem Ecology, 2nd ed.; Springer: Berlin/Heidelberg, Germany, 2011; pp. 187-188.

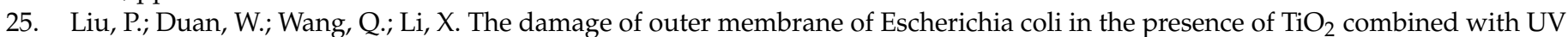
light. Colloids Surf. B Biointerfaces 2010, 78, 171-176. [CrossRef]

26. Miller, R.V.; Jeffrey, W.; Mitchell, D.; Elasri, M. Bacterial responses to ultraviolet light. ASM N. Am. Soc. Microbiol. 1999, 65, 535-541.

27. Hossain, M.S.; Rahman, N.N.N.A.; Balakrishnan, V.; Rajion, Z.A.; Kadir, M.O.A. Mathematical modeling of Enterococcus faecalis, Escherichia coli, and Bacillus sphaericus inactivation in infectious clinical solid waste by using steam autoclaving and supercritical fluid carbon dioxide sterilization. Chem. Eng. J. 2015, 267, 221-234. [CrossRef]

28. De Weerdt, K.; Plusquellec, G.; Belda Revert, A.; Geiker, M.R.; Lothenbach, B. Effect of carbonation on the pore solution of mortar. Cem. Concr. Res. 2019, 118, 38-56. [CrossRef]

29. Thomas, J.J.; Jennings, H.M.; Chen, J.J. Influence of nucleation seeding on the hydration mechanisms of tricalcium silicate and cement. J. Phys. Chem. C 2009, 113, 4327-4334. [CrossRef] 